\title{
Accessibility of children with special health needs to the health care network
}

\author{
Acesso de crianças com necessidades especiais de saúde à rede de atenção \\ El acceso de niños con necesidades especiales de salud a la red de atención
}

\section{Eliane Tatsch Neves' \\ ORCID: 0000-0002-1559-9533}

Aline Cristiane Cavicchioli Okido"

ORCID: 0000-0003-4309-5612

Fernanda Luisa Buboltz' ORCID: 0000-0002-2193-1707

Raíssa Passos dos Santos"II

ORCID: 0000-0003-4255-4004

Regina Aparecida Garcia de Lima'v

ORCID: 0000-0002-0611-5621

' Universidade Federal de Santa Maria. Santa Maria, Rio Grande do Sul, Brazil.

"Universidade Federal de São Carlos. São Carlos, São Paulo, Brazil.

"'McGill University. Montreal, Quebec, Canadá. "vniversidade de São Paulo. Ribeirão Preto, São Paulo, Brazil.

How to cite this article:

Neves ET, Okido ACC, Buboltz FL, Santos RP, Lima RAG. Accessibility of children with special health needs to the health care network. Rev Bras Enferm. 2019;72(Suppl 3):65-71. DOI: http://dx.doi.org/10.1590/0034-7167-2017-0899

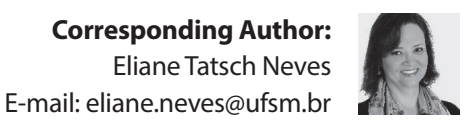

Submission: 02-14-2018 Approval: 10-22-2018

\begin{abstract}
Objective: To know how children with special health needs access the health care network. Method: This is a qualitative research of descriptive-exploratory type, developed using semi-structured interviews mediated by the Talking Map design. Participants were 19 family caregivers of these children in two Brazilian municipalities. Data were submitted to inductive thematic analysis. Results: Difficulties were mentioned from the diagnosis moment to the specialized follow-up, something represented by the itinerary of the $c$ hild and his/her family in the search for the definition of the medical diagnosis and the access to a specialized professional; a gap between the children's needs and the care offered was observed in primary health care. Conclusion: The access of children with special health needs is filled with obstacles such as slowness in the process of defining the child's diagnosis and referral to a specialist. Primary health care services were replaced by care in emergency care units. Descritores: Criança; Acesso aos Serviços de Saúde; Cuidadores; Doença Crônica; Enfermagem Pediátrica.
\end{abstract}

\section{RESUMO}

Objetivo: Conhecer como se dá o acesso de crianças com necessidades especiais de saúde na rede de atenção à saúde. Método: Pesquisa qualitativa do tipo descritivo-exploratória, desenvolvida por meio de entrevistas semiestruturadas mediadas pelo desenho do Mapa Falante. Participaram 19 familiares cuidadores dessas crianças em dois municípios brasileiros. Os dados foram submetidos à análise temática indutiva. Resultados: Apontou-se dificuldades, do diagnóstico ao acompanhamento especializado, algo denotado pelo itinerário da criança e sua família na busca pela definição do diagnóstico médico e pelo acesso ao profissional especializado; no atendimento na atenção primária à saúde, observou-se um distanciamento entre as necessidades das crianças e a assistência ofertada. Conclusão: $\mathrm{O}$ acesso de crianças com necessidades especiais de saúde apresenta-se permeado por obstáculos, como a morosidade no processo de definição diagnóstica da criança e o encaminhamento para o especialista. Houve substituição dos serviços da atenção primária pelos atendimentos em unidades de pronto-atendimento.

Descritores: Criança; Acesso aos Serviços de Saúde; Cuidadores; Doença Crônica; Enfermagem Pediátrica.

\section{RESUMEN}

Objetivo: Conocer cómo ocurre el acceso de niños con necesidades especiales de salud a la red de atención primaria a la salud. Método: Investigación cualitativa, de tipo descriptiva y exploratoria, en la cual se utilizó entrevistas semiestructuradas mediadas por la elaboración de un Mapa hablante. Participaron 19 familiares que cuidan a estos niños en dos municipios brasileños. Se sometieron los datos al análisis temático inductivo. Resultados: Del diagnóstico al acompañamiento especializado, se apuntaron dificultades durante la trayectoria del niño y su familia por la búsqueda de la definición del diagnóstico médico y del acceso al profesional especializado; en la atención en la red de atención primaria a la salud, se observó un distanciamiento entre las necesidades de los niños y la asistencia ofrecida. Conclusión: En el acceso de niños con necesidades especiales de salud ocurren numerosos obstáculos, como la morosidad en el proceso de definición diagnóstica del niño y su encaminamiento al especialista. Se observó una sustitución de los servicios de atención primaria por unidades de pronta atención.

Descriptores: Niño; Accesibilidad a los Servicios de Salud; Cuidadores; Enfermedad Crónica; Enfermería Pediátrica. 


\section{INTRODUCTION}

Technical and scientific development and the implementation of new policy guidelines led to the surfacing of the concept of children with special heath care needs $(\mathrm{CSHCN})^{(1)}$ in society known in Brazil as crianças com necessidades especiais de saúde $\left(\right.$ CRIANES) ${ }^{(2)}$. In the United States, approximately 11.2 million children and adolescents (15.1\%) have special health needs ${ }^{(3)}$. In Brazil, there are no specific epidemiological data about these children; however, CSHCN represent almost a quarter of the Brazilian child population ${ }^{(4)}$.

CSHCN are characterized by having different diseases and are classified according to their needs, not their medical diagnosis. According to a screening instrument developed in the United States, these needs include six areas: continued use of medications, use of medical services, use of mental health services or further psycho-pedagogical services when compared to other children, presence of functional limitation, need for rehabilitation therapy and treatment or counseling for emotional, developmental or behavioral problems ${ }^{(5)}$.

Previous studies reinforce that the caregivers of CSHCN perform a unique and complex care, which requires the effective participation of primary health care $(\mathrm{PHC})$ to support them in this process $^{(3-6)}$, hence the need to integrate primary care, the community, hospitals and specialized services to ensure continuity/ follow-up of care procedures ${ }^{(7)}$.

Findings from other studies with this population indicate that the health care network for these children is considered fragile and fragmented, being focused on specialized care at the expense of access to $\mathrm{PHC}^{(4,6,8)}$.

Given this context, this study was justified by the need to deepen and broaden the topic of access to the services that compose the health care network of CSHCN. The concepts of $\mathrm{PHC}$, health care network and health accessibility were used for the theoretical framework ${ }^{(9-11)}$.

Primary care services are characterized by providing greater efficiency in the flow of patients within the system, more effective treatment of chronic conditions, greater effectiveness in care, greater used of preventive practices, greater patient satisfaction and reduction of inequities in the accessibility to services and in the general health status of the population ${ }^{(9)}$.

Due to being characterized as the patient's gateway, PHC must be easily accessible. This is referenced both from a geographical point of view - factors related to location, distance and means of transportation to obtain care - and from a social and organizational point of view - factors and resources that facilitate or impair care ${ }^{(10)}$.

The health care network, included in the care model, starts from the essential assumptions that characterize it: the way of organizing the networks and the way in which they are articulated to meet the demands, chronic or acute ${ }^{(11)}$. Health care networks must be effective, efficient and of high quality, having availability of resources, quality of access, horizontal and vertical integration, well-defined territories and different care levels ${ }^{(11)}$.

Accessibility, in this study, is related to the use of the service, regardless of the health problem that affects people or the number of times they seek services. First-contact care is inserted as an attribution of $\mathrm{PHC}^{(12)}$. Accessibility thus refers to the use of a set of services in face of each new problem or new episode that causes the population to seek health care ${ }^{(11)}$.

\section{OBJECTIVE}

To know how children with special healthcare needs access the health care network.

\section{METHOD}

\section{Ethical aspects}

This research was approved by the Research Ethics Committee of Universidade Federal de Santa Maria and all ethical procedures for research involving human subjects were followed in accordance with the Brazilian Resolution No. 466/2012 of the Brazilian National Health Council.

\section{Type of study, place and period}

This is a qualitative research of descriptive-exploratory type characterized as a bicentric study, being developed in two Brazilian municipalities. Data collection occurred from May to October 2015. Municipality 1 (M1) is located in the countryside of the state of São Paulo, and Municipality 2 (M2) in the countryside of the state of Rio Grande do Sul. The results presented in this article constitute the qualitative phase of the matrix research "Prevalence and access of children with special healthcare needs in primary health care services".

Regarding the details of the study scenarios, the network of M1 is composed of 41 primary care facilities, of which 28 are Basic Health Units (UBS) and 13 are Family Health Units (USF). $\mathrm{M} 2$ is composed of 32 UBS, distributed in six health regions. Of the total UBS in the municipality, 13 are part of the Family Health Strategy (ESF). Since the sample design in phase I was by clusters, the study comprised eight units in Santa Maria (M2) and nine units in Ribeirão Preto (M1), including UBS and ESF.

\section{Study participants}

Study participants were 19 family caregivers selected intentionally from a sample of 407 caregivers, who were participants in the quantitative phase of the study. Eligibility criteria were: to be a family caregiver, older than 18 years, of children (up to 11 years, 11 months and 29 days) residing in the research municipalities. The participants were recruited from the PHC services.

Participants were selected according to the criteria of intentional sampling, which is characterized by gathering information-rich cases that could contribute to a deeper understanding of the studied phenomenon ${ }^{(13)}$. The intentional selection of participants considered socioeconomic indicators, family composition, use of public or private health services, types of special health needs and demands for care presented by the child. The number of participants was not stipulated a priori because this is a qualitative study.

To maintain the anonymity of the participants, an alphanumeric code with the letter $\mathrm{F}$ - for family member-, the sequential ordinal number of the interviews and the codes $\mathrm{M} 1$ for municipality 1 and M2 for municipality 2 (e.g., F1-M2, F3-M1). 


\section{Data collection and organization}

Data was produced from a semi-structured interview mediated by the dynamics of creativity and sensitivity (DCS). Two instruments were used: interview script with questions related to accessibility to health services, inspired on the child version of PCATool ${ }^{(9)}$, and application of an instrument for the characterization of participants considering clinical variables (number of hospitalizations, initial diagnosis, source of special health needs, current health diagnosis, follow-up at some health service, child using some sort of technology, demand for modified usual care, demand for neurodevelopmental therapy and updated vaccination calendar) and economic and socio-demographic variables (date and conditions of birth, birth complications, child's position in the family, family caregiver's current age, marital status, caregiver's years of formal study, family income, housing conditions and the presence of the child at school - and what kind of school).

The DCS Talking Map is a data production technique that aims to know the relationships established between caregivers and the community in general ${ }^{(14-15)}$. The following discussion question was asked: "Having your home as a starting point, what is (are) the place(s) where you take your child to receive health care and education, among other activities?".

After the participant was selected, an interview for a home visit previously scheduled by telephone was conducted. The collection period occurred from May to October 2015. The interviews lasted for approximately 80 minutes and were performed by the researchers responsible for each center, with the participation of research assistants.

All interviews were recorded in digital media and later submitted to independent double transcription. The corpus of the study consisted of the transcribed interviews and the images produced in the making of the Talking Map.

\section{Data analysis}

Data analysis was conducted via inductive thematic analysis ${ }^{(16)}$. The following steps were followed: familiarization with the data, generation of initial codes, search for themes, review of identified themes, definition and naming of themes and preparation of the final report ${ }^{(16)}$. Two themes emerged from the analysis: from the diagnosis process to specialized follow-up and care in PHC.

\section{RESULTS}

Regarding sample characterization, 10 participants were from $\mathrm{M} 1$ and nine from M2. In both municipalities, the age of CSHCN ranged from 5 to 11 years; the most common medical diagnoses by caregivers were neurological and respiratory system disorders, highlighting asthma and hyperactivity, respectively. Regarding special health needs, drug dependence and the use of health services were found in $100 \%$ of participants. With regard to caregivers, 95\% were mothers and grandmothers, considering that $100 \%$ of them use public health services. Considering the economic classification item, families were between the $C 2$ and DE ranges. The Brazilian Economic Classification Criteria, known as the Brazilian Criteria, is method for economic classification of the population based on the ownership of goods and access to public services, such as piped water and paved street. Each item on the Criteria receives a score. The Criteria ranges from $\mathrm{A}$ - highest rating - to E - lowest rating ${ }^{(17)}$.

\section{From the diagnosis to specialized care}

This theme regards the route of the child and how many times the family seeks care without having a defined medical diagnosis:

When she was 7 months old, she started having pneumonia. She would leave a pneumonia and 15 days later she would have it again, then she would leave this one and 15 days later have yet another case. She had 13 pneumonias. (F2-M1)

Searching for expedite in the diagnosis and onset of therapy, an M2 family caregiver resorted to private consultation - access to the private health system -, although without financial conditions for such:

A friend of mine called me and said that she would give the money to make an appointment with the doctor. (F3-M2)

Below, the Talking Map of F3-M2 illustrates the route of this family until the diagnosis was confirmed. In this case, dozens of emergency room visits happened.

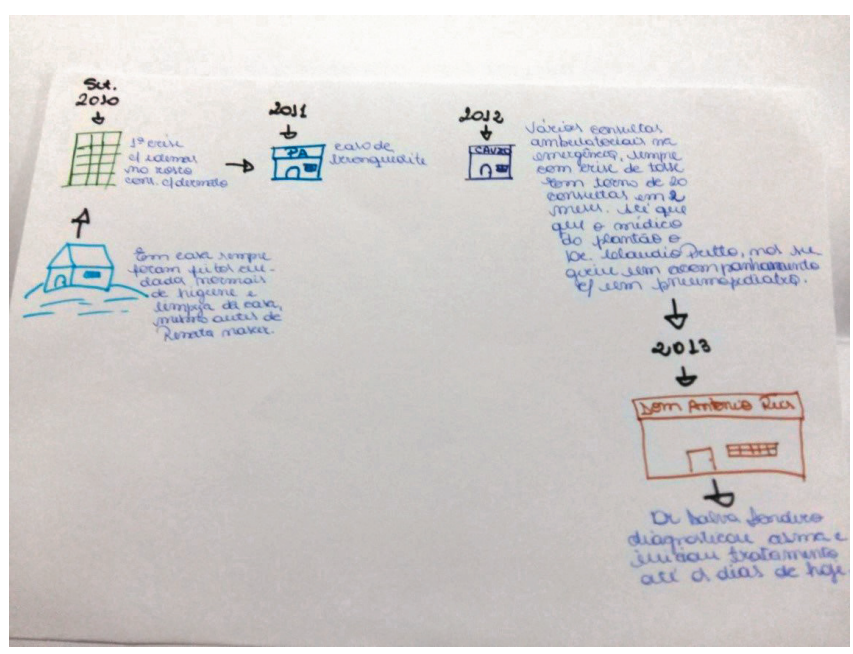

Figure 1 - Talking Map of F3-M2, Santa Maria, Rio Grande do Sul, Brazil, 2017

The figure illustrates the trajectory since 2010, with the first consultation; the years passed until 2013, when the child was referred to and attended by a specialized professional, who confirmed the asthma diagnosis.

After overcoming the obstacles to the identification and confirmation of the diagnosis, a new stage began: to ensure the accessibility to specialized care. From this perspective, family caregivers from the two municipalities reported similar experiences:

It is very hard for you to get the $\mathrm{HC}$ [Clinics Hospital]. I spent almost two years trying to get a spot. (F1-M1)

It's been two years we're waiting, and we have not been called yet. And over these two years he suffered many crises. (F1-M2) 
I think there is a lack of spots, because it is very hard to get one... she [the doctor] gave us the referral but it took us two months to get it. And she even assigned priority to our referral. (F2-M1)

It is the waiting time!! The waiting time to book an appointment is too long! If you have any urgency, as I said, it is impossible! Because it may be two months, depending on the doctor up to three. (F2-M2)

Regarding this context, the statement from $\mathrm{F} 1-\mathrm{M} 1$ is also relevant:

He was hospitalized in May, for three... three to four days. It was there when Doctor [Specialist] took his case. Now, the one treating him is the Doctor there in downtown. (F1-M1)

The hospitalization caused by complications was found to function as a shortcut in the search for a specialist. Thus, after learning about the clinical condition of the child during hospitalization, the professional specialist established an informal flow to enable access and continuity of post-discharge care.

The accessibility to the specialized service exceeds the guarantee of vacancy and concerns the logistical barriers, either by distance or by financial hardships:

It is how they play, there are places that are very far [...]. It's more difficult because he cannot ride the bus for a long time. (F6-M1)

Sometimes we do not have money and have to pay for the taxi. There was this one time he was sick, we spent 80 reais by taking taxis that week. That was the money we would use to purchase the medicine, because some medicine are not available at the BHU. (F4-M1)

The Talking Map below presents, metaphorically, the distance between the child's home and the different services where therapy occurs, sometimes requiring to use of two buses for such.

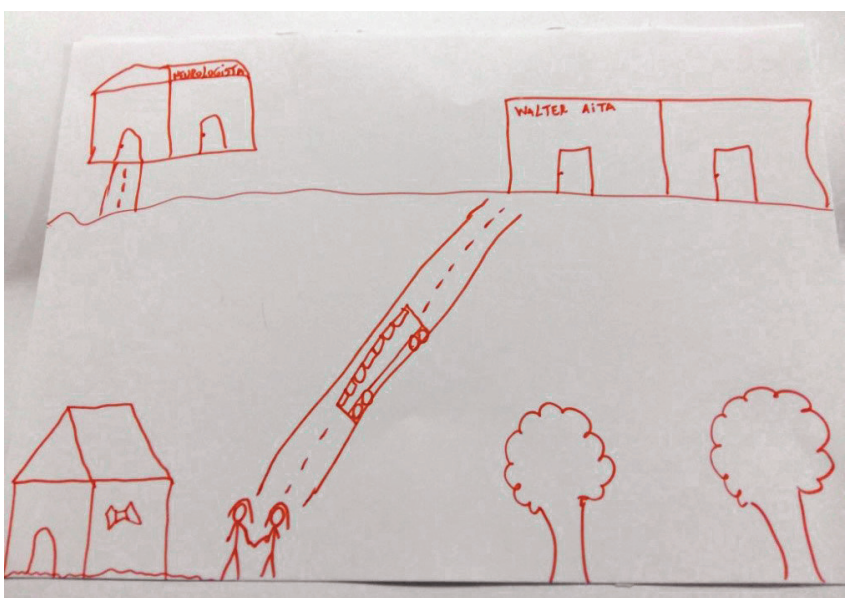

Figure 2 -Talking Map of F7-M2, Santa Maria, Rio Grande do Sul, Brazil, 2017

\section{Primary health care services}

The perception of family caregivers regarding PHC services, known as "postinhos de saúde" ("little medical centers"), was similar in both municipalities. The analysis found a gap between the needs of the CSHCN and their families and the care provided.
In this perspective, during the exacerbation of symptoms care must be sought in the emergency services, since the "postinho" prioritizes scheduled appointments:

Only when I have a scheduled appointment that it is good, if I go there while he's in a crisis, even if his nails are all purple, they do not want to see him, they tell us to go somewhere else. (F4-M1)

Basic unit? More or less! I do not like it very much! Because it only works with a scheduled appointment. In urgency when you really need it, they do not see you. (F6-M1)

Since PHC services usually do not efficiently absorb spontaneous demand, family caregivers come to understand the emergency care service as the ideal care space to the detriment of the health unit close to their home:

Here [at UBS] it's difficult, only in cases I do not have the time to go there [emergency service]. They already have a file for him at the emergency service, they are aware of his problem. So, for I to come here, to "postinho", it's only in a really difficult situation. I hardly come here. (F1-M2)

Another relevant aspect identified regards the valuation of the medical professional and the invisibility of the nursing team. The reports frequently record the pediatrician's assistance in PHC:

Based on Dr. N, it's very good! Very good! Because she is the one who looks, who identifies. She was the one who discovered everything. (F1-M1)

The pediatrician here is great, I cannot complain about her pediatrician. (F2-M1)

We must mention that all PHC units in $\mathrm{M} 1$ have a pediatrician. On the other hand, not all health units of $M 2$ have pediatricians. This reality was evaluated negatively, when the participants claimed that the absence of the pediatrician makes it difficult to bond with the units.

The work of the nursing team remains hidden as family caregivers revealed that health promotion and disease prevention actions were generally not systematized, even in cases where there were community health agents in the team:

Very difficult! But they do [referring to home visits]. Pretty rare. No one came this year. Last year they came here two or three times, but not this year. (F1-M1)

No! [referring to home visit] She [community agent] said she gives priority to the people who need the most. (F1-M2)

Another important aspect regards the role of $\mathrm{PHC}$ units as care coordinators to ensure the continuous and longitudinal aspects of care. When questioned about the knowledge of the child's clinical history and the evaluation and therapy indicated by the specialist, the family caregivers of $M 2$ stated that it only existed due to the informal report in the next consultation. In M2, this difficulty was mitigated due to the existence of an electronic medical record system, in which the care records are shared among the different 
services of the municipal health network. However, when CSHCN are followed-up in specialized services not belonging to the municipal health network, the problem is similar to $\mathrm{M} 2$.

\section{DISCUSSION}

The main findings of this study are delays in the diagnosis of the child, referral to specialized care, and difficulty in accessibility to primary care consultations when the chronic condition worsens.

Moreover, the results indicated that the most frequent medical diagnoses were asthma and hyperactivity, corroborating the international reality, considering that, in the United States, these diseases are among the main clinical conditions that affect $\mathrm{CSHCN}^{(18)}$. In a study developed in the southern region of Brazil in 2010, with 139 CSHCN, hyperactivity was also found as an expressive diagnosis ${ }^{(19)}$.

Regarding the care demands required by $\mathrm{CSHCN}$, the results of this study also corroborate Brazilian and international literature since, according to the American Academy of Pediatrics, these children usually take five times the number of medicines children in general take ${ }^{(20)}$. In Brazil, a study on 138 infants from a neonatal unit identified that $64.9 \%$ of them had drug dependence after hospital discharge ${ }^{(21)}$. Similarly, a study that aimed to understand the experience of mothers of children dependent on technology in relation to drug therapy also found that the continuous drug therapy these children undergo is frequent, both during hospitalization and at home ${ }^{(22)}$.

Mothers were found to be the main responsible for the care of $\mathrm{CSHCN}$, corroborating other studies developed with these children. According to the literature, although mothers receive support from family and friends, they take on the major part of care and become overloaded, developing physical and emotional exhaustion ${ }^{(23-24)}$.

The economic classification indicates a predominance of economically vulnerable families, corroborating the results of other research in affirming that the challenges experienced exceed the clinical frailty of the child and concern social vulnerabilities such as low income and the caregivers'low schooling levels, for example ${ }^{(15,25)}$.

The family of a CSHCN faces several difficulties when searching for the medical diagnosis, and subsequently, when searching accessibility to specialized care. The reports of pilgrimages while searching for care can be found in different studies. Thus, the difficulty in defining the medical diagnosis and the journey in several institutions denote the difficulty of access to services, configuring situations of social and programmatic vulnerability ${ }^{(8,26)}$. According to international literature, inequity in access to health services is common among CSHCN, especially for the subgroup of children with medical complexities ${ }^{(27)}$. The search for private services thus becomes a strategy adopted to ensure the resolution of problems ${ }^{(13,28)}$.

Another relevant aspect refers to geographical barriers; thus, when the specialized service is distant, service functionality is impaired $^{(12)}$. A systematic review of 61 articles on barriers to access to health services has shown that the coverage of health care is adversely affected by transport-related barriers, particularly for lower-income households ${ }^{(29)}$.

In the results, the perception of family caregivers regarding the role of PHC was not in line with the guidelines of the network, whose objective is to strengthen the actions of primary care services as a care coordinator, aiming to guarantee the continuous care and the strengthening of bonds between professionals, families and health institutions ${ }^{(11)}$. However, similar results have also been found in other studies, emphasizing that emergency services and tertiary services are preferred at the expense of primary level services, even to address the demands of $\mathrm{PHC}^{(8,12,28)}$. According to a Chilean study, when the attention to the health of CSHCN is focused on secondary and tertiary care services financial costs increase, the continuity of care is impaired and the accessibility to the benefits available in primary health care is restricted ${ }^{(30)}$.

The valuing of the pediatrician and the understanding that accessibility to the service occurs only from medical consultations reveals an overly biological conception of care by family caregivers. On the other hand, the literature reinforces that to overcome the current paradigm and picture of children's health, especially among $\mathrm{CSHCN}$, it is crucial to highlight the role of nurses in the process of development and implementation of $\mathrm{PHC}$ attributes in its entirety.

The work of the multidisciplinary team in the health care network proposal can offer a humanized and integral care to these children and their families, and the nurse must be the mediator between the patient and the team professionals, since nurses have the competencies to manage care ${ }^{(28)}$. In cases where psychosocial monitoring for children was required, caregivers considered the professionals, i.e., pediatric psychologists and psychiatrists, more difficult to access. When considering the mental health of children and adolescents we can find an important gap.

Failure to follow-up these children via home visits was also identified. Furthermore, the non-follow-up of these children by Family Health Strategy teams - home visit - denotes the non-fulfillment of one of the attributes of PHC, i.e., the longitudinal provision of care ${ }^{(12)}$, focusing the responsibility for the care and follow-up of children in specialized and emergency services. However, home visit is a work instrument capable of aggregating actions for health promotion, disease prevention and health surveillance in $\mathrm{PHC}^{(31-32)}$.

\section{Study limitations}

As a limitation of this study, we can consider the fact that it was developed in only two realities. Given the existing regional particularities and the wide range of differences in Brazil, the research should be expanded to other families of CSHCN in other health services of different regions.

\section{Contributions to the field of nursing, health or public policy}

As a contribution of this study, we must highlight the importance of discussing the attributes of $\mathrm{PHC}$ during the training of future professionals, as well as in the moments of permanent education in favor of the feasibility of accessibility and follow-up of CSHCN. For such, to value and optimize the space of primary care is fundamental, focusing on the promotion of health and prevention of injuries, especially of children who already have special health demands.

In the scope of nursing and health, it is believed that the range and viability of accessibility and follow-up in $\mathrm{PHC}$, made possible by professionals, can have impact on the reduction of morbidity and mortality, and in the quality of the lives of these children and their families.

It is hoped that studies like this will serve as subsidies for the elaboration of specific public policies for CSHCN, considering 
their uniqueness and singular health care demands in a multidisciplinary and integral way.

\section{CONCLUSION}

The results of this study identified the accessibility to the health care network as permeated by obstacles. Among the obstacles revealed by the family caregivers of $\mathrm{CSHCN}$, we can highlight the slowness in the process of defining the medical diagnosis of the child and his/her subsequent referral to a specialist, the logistic barriers to accessibility to specialized care and the gap between the needs of CSHCN and the care offered by PHC services. Moreover, the empirical material identified the valuing of the medical professional and the invisibility of the nursing team, as well as the replacement of PHC services by attendances in emergency care units.
Given the obstacles to ensure access to a specialist, the need for reorganization of health services must be considered, with a view to actions that lead to expedite in the processes of diagnosis and referral, such as the strengthening of health regulation. Regarding the role of emergency services and of the medical professional, it is suggested that Nursing, especially the PHC one, develops care actions that overcome the disease-centered model and ensure the access to the health care network. Home visits and health education groups can promote effective access to $\mathrm{PHC}$ and, consequently, strengthen the role of the nursing team.

\section{FUNDING}

This research was developed with the help of the National Council for Scientific and Technological Development (CNPq).

\section{REFERENCES}

1. McPherson M, Arango P, Fox H, Lauver C, McManus M, Newacheck PW, et al. A new definition of children with special health care needs. American Academy Pediatr. 1998;102(1):137-41. doi: 10.1542/peds.102.1.137

2. Docherty SL, Barfield R, Thaxton C, Brandon D. A qualidade de vida de crianças que vivem com doenças crônicas ou complexas. In: Hockenberry MJ, Wilson D, editores. Wong: fundamentos de enfermagem pediátrica. 9a ed. Rio de Janeiro: Elsevier; 2014. p. 515-47.

3. Caicedo C. Children with special health care needs: child health and functioning outcomes and health care service use. J Pediatr Health Care. 2016;30(6):590-8. doi: 10.1016/j.pedhc.2015.12.003

4. Cabral IE, Moraes JRMM. Family caregivers articulating the social network of a child with special health care needs. Rev Bras Enferm. 2015;68(6):769-76 doi: 10.1590/0034-7167.2015680612i

5. Bethell CD, Read D, Blumberg SJ, Newacheck PW. What is the prevalence of children with special health care needs? Toward an understanding of variations in findings and methods across three national surveys. Matern Child Health J. 2008;12(1):1-14. doi: 10.1007/ s10995-007-0220-5

6. Astolpho MP, Okido ACC, Lima RAG. Rede de cuidados a crianças com necessidades especiais de saúde. Rev Bras Enferm. 2014;67(2):213-9. doi: 10.5935/0034-7167.20140028

7. Rucci P, Latour J, Zanello E, Calugi S, Vandini S, Faldella G, et al. Measuring parents' perspective on continuity of care in children with special health care needs. Int J Integr Care. 2015;15:e046. doi: 10.5334/ijic.2202

8. Neves ET, Silveira A, Arrué AM, Pieszak GM, Zamberlan KC, Santos RP. Network of care of children with special health care needs. Texto Contexto Enferm. 2015;24(2):399-406. doi: 10.1590/0104-07072015003010013

9. Starfield B. Atenção primária: equilíbrio entre necessidades de saúde, serviços e tecnologia [Internet]. Brasília: UNESCO, Ministério da Saúde; 2002 [cited 2017 Mar 12]. Available from: http://www.conass.org.br/bibliotecav3/pdfs/colecao2011/livro_3.pdf

10. Conselho Nacional de Secretários de Saúde (CONASS). Atenção primária e promoção da saúde [Internet]. Brasília: CONASS; 2011 [cited 2017 Mar 12]. Available from: http://www.conass.org.br/bibliotecav3/pdfs/colecao2011/livro_3.pdf

11. Mendes EV. As redes de atenção à saúde [internet]. 2a ed. Brasília: Organização Pan-Americana da Saúde; 2011 [cited 2017 Mar 12]. Available from: http://bvsms.saude.gov.br/bvs/publicacoes/redes_de_atencao_saude.pdf

12. Silva RMM, Viera CS. Acesso ao cuidado à saúde da criança em serviços de atenção primária. Rev Bras Enferm. 2014;67(5):794-802. doi: 10.1590/0034-7167.2014670518

13. Moreira H, Caleffe LG. Metodologia da pesquisa para o professor pesquisador. Rio de Janeiro: DP\&A; 2006.

14. Cabral IE, Neves ET. Pesquisar com o método criativo e sensível na enfermagem: fundamentos teóricos e aplicabilidade. In: Lacerda MR, Costenaro RGS, organizadoras. Metodologias da pesquisa para a enfermagem e saúde. Porto Alegre: Moriá; 2015.

15. Silveira A, Neves ET. Vulnerability of children with special health care needs: implications for nursing. Rev Gaúcha Enferm. 2012;33(4):172-80. doi: 10.1590/S1983-14472012000400022

16. Braun V, Clarke V. Using thematic analysis in psychology. Qual Res Psychol. 2006;3(2):77-101. doi: 10.1191/1478088706qp063oa

17. Associação Brasileira de Empresas de Pesquisa (ABEP). Critério de Classificação Econômica Brasil: Critério Brasil 2015 e atualização da distribuição de classes para 2016 [Internet]. São Paulo: ABEP; 2016 [cited 2017 Nov 20]. Available from: http://www.abep.org/criterio-brasil

18. Centers for Disease Control and Prevention (CDC). National Survey of Children with Special Health Care Needs [Internet]. Atlanta: CDC; 2012 [cited 2016 Jul 15]. Available from: https://www.cdc.gov/nchs/slaits/cshen.htm 
19. Arrué AM, Neves ET, Terra MG, Magnago TSBS, Jantsch LB, Pieszak GM, et al. Crianças/adolescentes com necessidades especiais de saúde em Centro de Atenção Psicossocial. Rev Enferm UFSM. 2013;3(2):227-37. doi: 10.5902/217976927827

20. Elias ER, Murphy NA. Home care of children and youth with complex health care needs and technology dependencies. Pediatrics. 2012;129(5):996-1005. doi: 10.1542/peds.2012-0606

21. Tavares TS, Duarte ED, Silva BCN, Paula CM, Queiroz MPM, Sena RR. Caracterização do perfil das crianças egressas de unidade neonatal com condição crônica. R Enferm Cent O Min. 2014;3(4):1322-35. doi:10.19175/recom.v0i0.802

22. Okido ACC, Cunha ST, Neves ET, Dupas G, Lima RAG. Technology-dependent children and the demand for pharmaceutical care. Rev Bras Enferm. 2016;69(4):671-7. doi: 10.1590/0034-7167.2016690415i

23. Okido ACC, Zago MMF, Lima RAG. Care for technology dependent children and their relationship with the health care systems. Rev LatinoAm Enfermagem. 2015;23(2):291-8. doi: 10.1590/0104-1169.0258.2554

24. Ferreira MC, Di Naccio BL, Otsuka MYC, Barbosa AM, Corrêa PFL, Gardenghi G. Assessing the burden on primary caregivers of children with cerebral palsy and its relation to quality of life and socioeconomic aspects. Acta Fisiátr. 2016;22(1):9-13. doi: 10.5935/0104-7795.20150003

25. Looman WS, Presler E, Erickson MM, Garwick AE, Cady RG, Kelly AM, et al. Care coordination for children with complex special health care needs: the value of the Advanced Practice Nurse's Enhanced Scope of Knowledge and Practice. J Pediatr Health Care. 2013;27(4):293-303. doi: 10.1016/j.pedhc.2012.03.002

26. Costa EAO, Dupas G, Sousa EFR, Wernet M. Children's chronic disease: family needs and their relationship with the family health strategy. Rev Gaúcha Enferm. 2013;34(3):72-8 doi: 10.1590/S1983-14472013000300009

27. Kuo DZ, Goudie A, Cohen E, Houtrow A, Agrawal R, Carle AC, et al. Inequities in health care needs for children with medical complexity. Health Aff (Millwood). 2014;33(12):2190-8. doi: 10.1377/hlthaff.2014.0273

28. Buboltz FL, Silveira A, Neves ET. Strategies for families of children served in pediatric first aid: the search for the construction of integrality. Texto Contexto Enferm. 2015;24(4):1027-34. doi: 10.1590/0104-0707201500002040014

29. Syed ST, Gerber BS, Sharp LK. Traveling towards disease: transportation barriers to health care access. J Community Health. 2013;38(5):97693. doi: 10.1007/s10900-013-9681-1

30. Flores Cano JC, Calvo ML, Zamora NR, Anguita MEA, De La Paz MG, Yañez SB, et al. Models of care and classification of "Children with special health care needs-CSHCN": recommendations from the CSHCN Committee, Chilean Paediatric Society. Rev Chil Pediatr. 2016;87(3):224-32. doi: 10.1016/j.rchipe.2016.03.005

31. Nakata PT, Koltermann LI, Vargas KR, Moreira PW, Duarte ERM, Rosset-Cruz I. Classification of family risk in a family health center. Rev LatinoAm Enfermagem. 2013;21(5):1088-95. doi: 10.1590/S0104-11692013000500011

32. Nascimento JS, Costa LMC, Santos RM, Anjos DS. Home visits as a strategy for health promotion by nursing. Rev Bras Promoc Saúde. 2013;26(4):510-8. doi: 10.5020/3116 